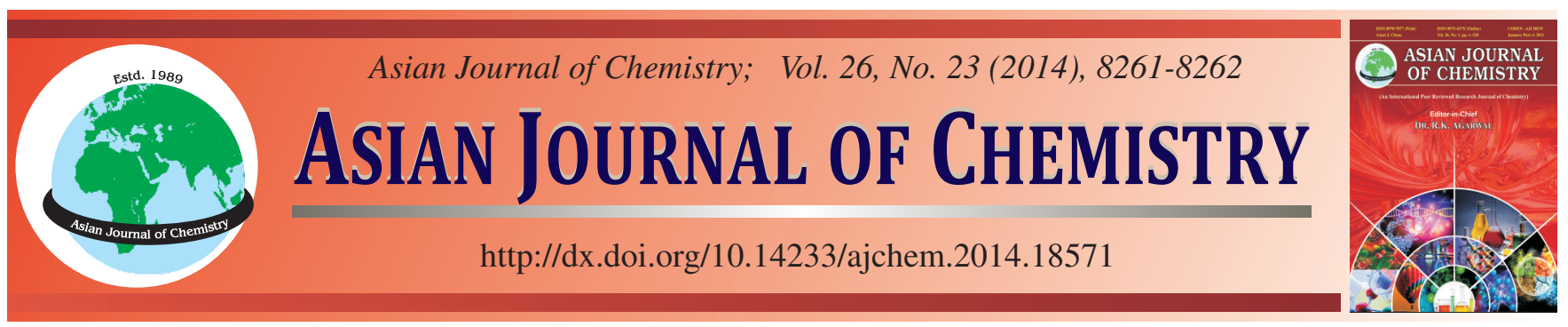

NOTE

\title{
Phytol May Inspire New Medicinal Foods for the Treatment of Heart Disease
}

\author{
B. Pejin ${ }^{1, *}$, T. Kartali ${ }^{2}$, B. Stanimirovic ${ }^{3}$ and M. Karaman ${ }^{2}$
}

\begin{abstract}
${ }^{1}$ University of Belgrade, Institute for Multidisciplinary Research - IMSI, Department of Life Sciences, Kneza Viseslava 1, 11030 Belgrade, Serbia ${ }^{2}$ University of Novi Sad, Faculty of Sciences, Department of Biology and Ecology, Trg Dositeja Obradovica 2, 21000 Novi Sad, Serbia ${ }^{3}$ Institute MOL Ltd, Nikole Tesle 15, 22300 Stara Pazova, Serbia
\end{abstract}

*Corresponding author: E-mail: brspjn@gmail.com, boris.pejin@imsi.rs

Received: 8 August 2014; $\quad$ Accepted: 30 September 2014; $\quad$ Published online: 15 November 2014; $\quad$ AJC-16341

This study aimed to investigate in vitro antibacterial activity of phytol against the selected Gram positive bacteria (Clostridium sporogenes, Enterococcus faecalis and Sarcina lutea) involved in the pathogenesis of infective endocarditis. The examined natural product has proved to be active against all the tested bacteria, but to a varying degree. Indeed, phytol inhibited $E$. faecalis growth (MIC $1.56 \pm 0.04 \mu \mathrm{g} / \mathrm{mL}$ ) more effectively than gentamycin and ampicillin (MIC $5.00 \pm 0.06$ and $16.00 \pm 0.03 \mu \mathrm{g} / \mathrm{mL}$, respectively). Both its freely presence in nutrition and easy availability support the development of a new phytol based medicinal foods targeting heart disease.

Keywords: Diterpene alcohol, Antibacterial activity, Enterococcus faecalis, Infective endocarditis.

Traditional Chinese medicine suggests that some mosses of the genus Rhodobryum (Bryaceae) can be used as crude drugs for heart disease ${ }^{1}$. Actually, this genus includes four species present in northern hemisphere ${ }^{2}$ together with some additional ones from subtropical or tropical regions ${ }^{3}$. The moss Rhodobryum ontariense has a wide but very fragmented distribution ${ }^{4}$. Preliminary analysis of its volatiles has indicated phytol as the main constituent $(31.95 \%)^{5}$. Such abundance of this natural product has not previously been reported in essential oils of other mosses ${ }^{6}$.

Phytol (3,7,11,15-tetramethyl-2-hexadecen-1-ol) is an acyclic monounsaturated diterpene alcohol, present in vitamin $\mathrm{K}$, vitamin $\mathrm{E}$ and other tocopherols. It is an active ingredient in formulations that lower serum levels of triglycerides and/or cholesterol $^{7}$. Indeed, this compound may be administered both to patients (e.g. with type II diabetes, obesity or heart disease) and healthy individuals ${ }^{8}$.

A large body of evidence implicates number of microbial strains in the pathogenesis of infective endocarditis (IE) $)^{9,10}$. Enterococci are the third most common etiologic agent of IE worldwide after Staphylococci and Streptococci being responsible for 10 to $15 \%$ of cases ${ }^{11}$. Approximately $90 \%$ of the enterococcal endocarditis cases are caused by Enterococcus faecalis, with $<5 \%$ by E. faecium. The bacteria Clostridium sporogenes and Sarcina lutea are also listed among the microorganisms which might provoke $\mathrm{IE}^{12,13}$.
The aim of this study was to investigate in vitro antibacterial activity of phytol against three IE bacteria for the first time.

The examined chemical was used as received from SigmaAldrich, Munich, Germany (97\%, mixture of isomers), without any further purification. The Gram-positive bacteria Clostridium sporogenes ATCC 19404, Enterococcus faecalis ATCC 19433 and Sarcina lutea ATCC 9341 were obtained from the Mycological Laboratory, Faculty of Sciences, University of Novi Sad, Novi Sad, Serbia. The antibacterial assay was carried out by a 96 well microdilution method ${ }^{14}$. Gentamycin (Sigma-Aldrich, Munich, Germany) and ampicillin (Panfarma, Belgrade, Serbia) were used as a positive control, respectively. All experiments were performed in duplicate and repeated three times.

Phytol has showed to be active against all the tested bacteria, with MIC and MBC values 1.56-6.25 and > $12 \mu \mathrm{g} / \mathrm{mL}$, respectively (Table-1).

The most susceptible bacterium was E. faecalis. Actually, this organic compound inhibited E. faecalis growth more effectively ( $\mathrm{MIC}<2 \mu \mathrm{g} / \mathrm{mL}$ ) than gentamycin and ampicillin (MIC 5 and $16 \mu \mathrm{g} / \mathrm{mL}$, respectively). The reports on phytol antibacterial activity are relatively scarce. Rajab et al. ${ }^{15}$ reported a MIC value of $2 \mu \mathrm{g} / \mathrm{mL}$ against the IE bacterium Mycobacterium tuberculosis for $(E)$-phytol, $(Z)$-phytol, commercially available $2: 1$ mixture of $(E)$ and $(Z)$-phytol and $(3 R, S, 7 R, 11 R)$ - 


\begin{tabular}{|c|c|c|c|}
\hline \multicolumn{4}{|c|}{$\begin{array}{c}\text { TABLE-1 } \\
\text { MINIMUM INHIBITORY (MIC) AND BACTERICIDAL }\end{array}$} \\
\hline Bacteria & Phytol $^{* ¥}$ & Gentamicin $^{* \# ¥}$ & Ampicillin ${ }^{* \# ¥}$ \\
\hline Clostridium sporogenes ATCC 19404 & $3.12 \pm 0.08 />12$ & $2.50 \pm 0.02 />20$ & $64.00 \pm 0.06 />128$ \\
\hline Enterococcus faecalis ATCC 19433 & $1.56 \pm 0.04 />12$ & $5.00 \pm 0.06 />20$ & $16.00 \pm 0.03 />128$ \\
\hline Sarcina lutea ATCC 9341 & $6.25 \pm 0.06 />12$ & $2.50 \pm 0.03 />20$ & $2.00 \pm 0.03 />2$ \\
\hline
\end{tabular}

phytanol, respectively. Furthermore, the derivatives $(E)$-phytol acetate, a mixture of the $(2 S, 3 S)$ - and $(2 R, 3 R)$-isomers of $(E)$ phytol epoxide and $(3 R, S, 7 R, 11 R)$-phytanic acid displayed lower activities with MICs of 8,16 and $>128 \mu \mathrm{g} / \mathrm{mL}$, respectively ${ }^{15}$. On the other hand, Pejin et al. ${ }^{16}$ reported a MIC value of $3 \mu \mathrm{g} / \mathrm{mL}$ against the IE bacterium Listeria monocytogenes for the phytol sample screened herein.

Phytol is a common and nonmutagenic food additive, with satisfactory safety. In addition, it is structurally simple, easily available and cost-effective chemical ${ }^{17}$. The low toxicity and high tolerance by mammals make this terpene molecule good candidate for the key ingredient of a new medicinal foods targeting heart disease.

\section{ACKNOWLEDGEMENTS}

This work was supported by the Ministry of Education, Science and Technological Development of the Republic of Serbia (Research grants Nos. 172053, 173017 and III43002).

\section{REFERENCES}

1. E.S.J. Harris and B. Yang, Econ. Bot., 63, 190 (2009).

2. T. Koponen, Ann. Bot. Fenn., 3, 399 (1966).

3. A.J.E. Smith, The Moss Flora of Britain and Ireland, Cambridge University Press, Cambridge, pp. 1012 (2004).
4. K. Dierssen, in ed.: J. Cramer, Distribution, Ecological Amplitude and Phytosociological Characterization of European Bryophytes, ed., Bryophytorum Bibliotheca, Vol. 56, Berlin, p. 289 (2001).

5. B. Pejin, Lj. Vujisic, M. Sabovljevic, V. Tesevic and V. Vajs, Cryptogamie Bryol., 32, 113 (2011).

6. T. Özdemir, N. Yayli, T.B. Cansu, C. Volga and N. Yayli, Asian J. Chem., 21, 5505 (2009).

7. P. Olofsson, M. Hultqvist and R. Holmdahl, United States Patent Application Publication, Appl. No. 12/921,169 (2011).

8. M.M. Elmazar, H.S. El-Abhar, S.M.F. Chaalan and N.A. Farag, PLoS ONE, 8, e45638 (2013).

9. D. Kumar, J.J. Cawley, J.M. Irizarry-Alvarado, A. Alvarez and S. Alvarez, Transpl. Infect. Dis., 9, 336 (2007).

10. R.S. Mitchell, V. Kumar, S.L. Robbins, A.K. Abbas and N. Fausto, Robbins Basic Pathology, Saunders/Elsevier, Philadelphia, pp. 960 (2007).

11. J.M. Miro, J.M. Pericas and A. del Rio, Circulation, 127, 1763 (2013).

12. L. Clontz, Microbial Limit and Bioburden Tests: Validation Approaches and Global Requirements, CRC Press, Boca Raton, pp. 280 (2009).

13. G. Miltiadous and M. Elisaf, J. Med. Case Reports, 5, 251 (2011).

14. M. Karaman, N. Mimica-Dukic, P. Knezevic, Z. Svircev and M. Matavuly, Int. J. Med. Mushrooms, 11, 269 (2009).

15. M.S. Rajab, C.L. Cantrell, S.G. Franzblau and N.H. Fischer, Planta Med., 64, 2 (1998).

16. B. Pejin, A. Savic, M. Sokovic, J. Glamoclija, A. Ciric, M. Nikolic, K. Radotic and M. Mojovic, Nat. Prod. Res., 28, 372 (2014).

17. J.-F. Rontani and J.K. Volkman, Org. Geochem., 34, 1 (2003). 